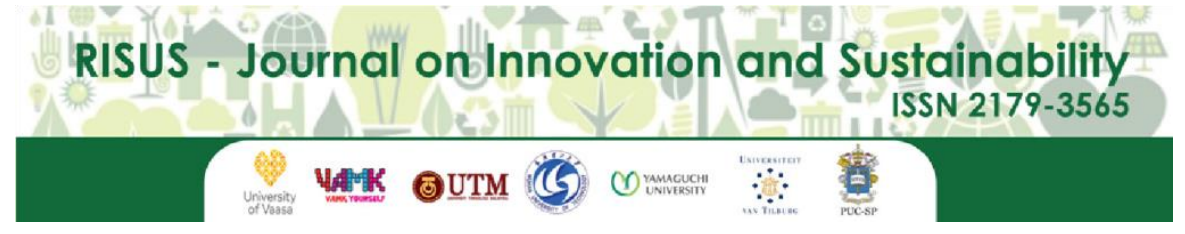

RISUS - Journal on Innovation and Sustainability volume 11, número 1 - 2020

ISSN: $2179-3565$

Editor Científico: Arnoldo José de Hoyos Guevara Editor Assistente: Rosa Rizzi

Avaliação: Melhores práticas editoriais da ANPAD

\title{
DIGITAL TRANSFORMATION IN HEALTHCARE SERVICES SECTOR OF BANGLADESH: CURRENT STATUS, CHALLENGES AND FUTURE DIRECTION
}

Transformação digital no setor de serviços de saúde de Bangladesh: status atual, desafios e direção futura

$$
\text { Mohammad Zahedul Alam }{ }^{1,2} \text {, Wang } \mathrm{Hu}^{1} \text {, Md. Aslam Uddin }{ }^{3}
$$

1 School of Management, Wuhan University of Technology, Wuhan, P.R.China, 430070

2 Department of Marketing, Bangladesh University of Professionals, Bangladesh

3 Department of Marketing, Bangladesh University of Business \& Technology, Bangladesh

Email: zaheddu2000@yahoo.com,wanghu61@126.com, aslam@bubt.edu.bd

\begin{abstract}
Digital transformation in healthcare services has massive potential to ensure healthcare quality, accessibility, equality \& affordability in developing countries. Bangladesh is not exception to this trend for digitalization of healthcare sector as a part of vision 2021 of digital Bangladesh. This paper aims to explore the current standing of the digital transformation in healthcare services sector of the public, private \& NGOs, as well as the managerial and technical challenges facing the digitalization of healthcare projects in Bangladesh. The digital transformation in healthcare is at the introductory stage in Bangladesh. Studies explored that although digitalization of this sector remains somewhat problematic, the difficulties and challenges could be overcome. Due to lack of technological knowhow, literacy, poverty, trust, attitudes, resistance to change and infrastructural facilities, this project does not work effectively and efficiently. Based on the assessment of this sector, the scope of some fields requires further improvement. The findings will help government agencies, policymakers, healthcare providers and mobile phone companies to make effective decisions regarding the digitalization of Healthcare services.
\end{abstract}

Keywords: Digital transformation. Healthcare. Challenges. Bangladesh. etc

\section{ACEITO EM: 30/01/2020}

PUBLICADO: 30/05/2020 


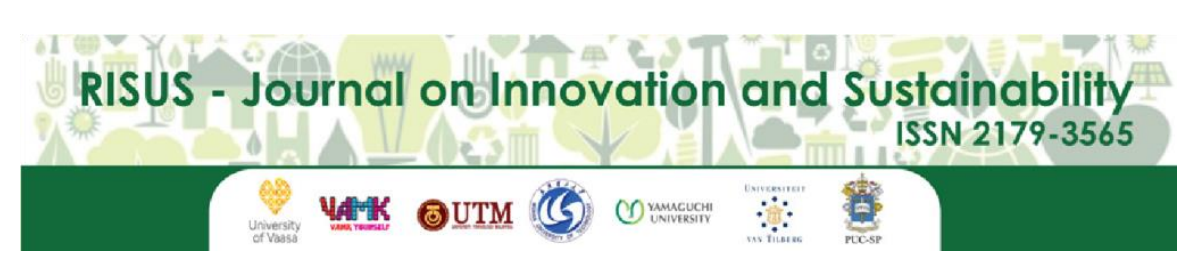

RISUS - Journal on Innovation and Sustainability volume 11, número1 - 2020 ISSN: $2179-3565$

Editor Científico: Arnoldo José de Hoyos Guevara Editor Assistente: Rosa Rizzi Avaliação: Melhores práticas editoriais da ANPAD

\title{
TRANSFORMAÇÃO DIGITAL NO SETOR DE SERVIÇOS DE SAÚDE DE BANGLADESH: STATUS ATUAL, DESAFIOS E DIREÇÃO FUTURA
}

\author{
Digital transformation in healthcare services sector of bangladesh: \\ current status, challenges and future direction
}

\author{
Mohammad Zahedul Alam ${ }^{1,2}$, Wang $\mathrm{Hu}^{1}$, Md. Aslam Uddin ${ }^{3}$ \\ 1 School of Management, Wuhan University of Technology, Wuhan, P.R.China, 430070 \\ 2 Department of Marketing, Bangladesh University of Professionals, Bangladesh \\ 3 Department of Marketing, Bangladesh University of Business \& Technology, Bangladesh \\ Email: zaheddu2000@yahoo.com,wanghu61@126.com, aslam@bubt.edu.bd
}

\section{RESUMO}

A transformação digital nos serviços de saúde tem um enorme potencial para garantir a qualidade, acessibilidade, igualdade e acessibilidade da assistência médica nos países em desenvolvimento. Bangladesh não é exceção a esta tendência de digitalização do setor de saúde como parte da visão 2021 do Bangladesh digital. Este artigo tem como objetivo explorar a atual posição da transformação digital no setor de serviços de saúde do público, privado e ONGs, bem como os desafios gerenciais e técnicos enfrentados pela digitalização de projetos de saúde no Bangladesh. A transformação digital em saúde está na fase introdutória em Bangladesh. Estudos exploraram que, embora a digitalização desse setor permaneça um tanto problemática, as dificuldades e os desafios podem ser superados. Devido à falta de conhecimento tecnológico, alfabetização, pobreza, confiança, atitudes, resistência à mudança e instalações de infraestrutura, este projeto não funciona de maneira eficaz e eficiente. Com base na avaliação desse setor, o escopo de alguns campos exige melhorias adicionais. As conclusões ajudarão agências governamentais, formuladores de políticas, provedores de assistência médica e empresas de telefonia móvel a tomar decisões efetivas em relação à digitalização dos serviços de assistência médica.

Palavras-Chave: Transformação digital. Cuidados de saúde. Desafios. Bangladesh. etc 


\section{INTRODUCTION}

As a result of rapid globalization and the exponential advancement in information and communication technology (ICT), healthcare sector has been changed dramatically over the past decade in many countries of the world. The diffusion rate of digital technologies in this sector has quickly progressed over the past ten years (Ivatury et. al., 2016). Digital transformation of healthcare could be the keystone of a successful reform of healthcare systems for improved efficiency and effectiveness for the benefit of the people. Recently, Information and communication technologies have transformed all sectors of society. The health sector is no exception to this trend. Digital transformation of healthcare creates an exciting, new realm of possibilities for medical services in rural areas that are simultaneously experiencing growth and renewal (Alami, 2017). Healthcare is a critical part of the economy of Bangladesh and improving the healthcare sector is one of the sustainable development goals. In addition, Health performance and economic performance are interlinked. But problems such as excessive costs, insufficient resources, uneven quality levels and inequalities in terms of access to healthcare plague the current healthcare industry. As a part of vision 2021 of digital Bangladesh, the application of ICT to healthcare, especially digital services are explosively advancing. Research on the adoption of e-Health which is the part of digitalization in developing countries, has shown that eHealth/mHealth can be potential solutions to provide better access to healthcare facilities for patients, physician, nurses and other healthcare staffs, increase care quality and improve collaboration (Khalifehsoltani \& Gerami, 2010).

Like other developed and developing countries, healthcare sector has become the blessing of ICT in Bangladesh which has been recognized as one of 57 countries in the world with a critical shortage in health workforces (hospitals, doctors, nurses and midwives number below 2.28 per 1000 population) and number of beds (4 per 10,000) in hospitals (Mostafa R., 2016). Bangladesh has an extreme scarcity of well-trained nurses, physicians and healthcare resources in comparison to the international standard (i.e. the nurse-patient ratio is 1:4 for general care, and 1:1 for intensive care). In Bangladesh, these ratios are 1:13 for general patients and physicians outnumber nurses with a ratio of 1.3:1 (Ministry of Planning, BD, 2017). So, effective initiatives need to be undertaken to improve these ratios significantly by 2021. In addition, providing affordable, accessible, equal and adequate healthcare is a challenge due to poor healthcare infrastructure and high population density. Due to explosive growth of population, poor sanitation, chronic diseases and Bangladesh faces double burden of diseases: Non-Communicable diseases: Diabetes, Cardiovascular diseases, Hypertension, Stroke, Chronic respiratory diseases, Cancer and Communicable diseases: Tuberculosis, HIV, Tetanus, Malaria, Measles, Rubella, leprosy and so on.

In order to overcome these problems, the government has started a new initiative in the health sector by incorporating digital technology for health service delivery which is a part of making digital Bangladesh by 2021. But, there are extremely few well trained individuals and there is a strong demand for capacity building and experience sharing, especially for implementation and policy making (Ahmed et. al., 2014). Most previous studies have only focused on the application of eHealth, in Bangladesh like m-Health, telemedicine, electronic health record, telecare (Hoque at el., 2014). Unfortunately, there is lack of investigation of the current status of digital transformation in health care sector of Bangladesh. So, it is imperative to examine the current status of digital transformation in health sector of public, private sector \& NGOs, challenges of digitalization and finally provide recommendations \& future direction at the end. 


\section{KEY CONCEPT OF DIGITAL TRANSFORMATION IN HEALTHCARE SECTOR}

Expansion of the computer networking is the absolute marvel that makes possible the digital transformation of health care. Impressive advances in programming languages and operating systems over the past few years also have solidified the foundations of digital health care (Jeffrey C. Bauer, 2002). Digitalization includes key areas i.e. reconfiguring the customer value proposition-what is being offered-and reshaping the operating model-how it is delivered. It is generally understood to be the application of Computer, Internet, Mobile phone and other technologies to improve the patients' health status. It involves the use of information technologies to improve health in general and the healthcare system in particular. Given the right policies, organizations, resources, and institutions, ICTs can be powerful tools in the hands of those working to improve healthcare. Surprisingly, this sector has been characterized with some uniqueness that patients have fewer selfservice options than they have in other sectors, and less access to trusted information on the quality of care on offer. With regard to the potential for digital and social media, healthcare is distinct from other sectors in several important ways (Erwin Bellon, 2016).

\section{CURRENT STATUS}

Digitalization in healthcare services sector is at the infant stage in Bangladesh. In fact, Bangladesh has not yet been prepared to properly cope with the adoption of ICT in the healthcare services sector. There are no specific rules and regulations for applying ICT efficiently and effectively in healthcare sector. In Bangladesh, the role of ICT depends on specific circumstances and some applications of ICT are more used than others. With the exponential progression of internet usages, Bangladesh has stepped down two ranks in the global ICT Development Index by securing $145^{\text {th }}$ among 175 countries (Khatun F., 2015). The following table 1 shows the exponential growth of the number of internet users in Bangladesh from 2005 to 2017. Sources: Statista, 2018

Table 1 The Numbers of Internet Users in Bangladesh from 2005 to 2017 (Millions)

\begin{tabular}{l|lllllllllllll} 
Years & 2005 & 2006 & 2007 & 2008 & 2009 & 2010 & 2011 & 2012 & 2013 & 2014 & 2015 & 2016 & 2017 \\
\hline Users & 0.36 & 1.45 & 2.64 & 3.71 & 4.65 & 5.61 & 6.90 & 7.76 & 10.42 & 15.27 & 19.42 & 21.44 & 70.0
\end{tabular}

Currently, Bangladesh is adopting an ambitious national ICT/eHealth policy to incorporate ICTs into their health system, aligning with the Digital Bangladesh Vision 2021. For example, Current initiatives are internet connectivity and doctors' access via mobile phone at over 800 health centers; video conferencing facilities in community clinics; database for health policy planning; OMR based patient-level data collection; rudimentary telemedicine piloted by NGOs; mobile-based helpline with doctors. These digital transformations in healthcare sector spread throughout the digital channel, digital startup and digital initiatives for social impact which are discussed in detailed in the following sections.

\subsection{Digital channel}

Under the umbrella of digitalization, the digital channels are incorporated into the healthcare service providers such as are telehealth, telecare, mHealth, eHealth, Electronic Health Record (EHR), Video Conferencing, Telemedicine etc. There are 26 initiatives with direct or indirect associations with mHealth and or eHealth in Bangladesh. These initiatives were undertaken by private (15.4\%), private for profit $(53.8 \%)$, private not for profit (15.4\%) \& NGOs (15.4\%) (Ahmed et al., 2014). 


\subsection{Digital startup}

The digital healthcare movement is driving a vast array of startups in Dhaka city, many working in mobile healthcare and healthcare for the last mile population. The following table 2 shows the digital startup operated in Bangladesh.

Table 2 Digital Startup Operated in Bangladesh

\begin{tabular}{|c|c|}
\hline Digital Startup & Remarks \\
\hline Doctorola & $\begin{array}{l}\text { It provides eService to mass people i.e. appointment of doctor, live } \\
\text { chat, mobile apps and call center. }\end{array}$ \\
\hline Jeeon & $\begin{array}{l}\text { It organizes training program for local intermediaries and provides } \\
\text { equipment to facilitate consultations with remote doctors in order to } \\
\text { provide quality healthcare services to rural patients. }\end{array}$ \\
\hline $\mathrm{Rx} 71$ & $\begin{array}{l}\text { It builds a huge platform of health related content in Bangla for } \\
\text { creating health awareness and educating people on health issues in } \\
\text { their daily life. }\end{array}$ \\
\hline Tonic & $\begin{array}{l}\text { It makes information and suggestions about health and illness, } \\
\text { positive health change and editorial style content. }\end{array}$ \\
\hline Doctors.bd.com & $\begin{array}{l}\text { It has database regarding blood donor, hospital, medical institute, } \\
\text { diagnostic center, clinic, kidney/eye bank and online consultations } \\
\text { within } 24 \text { hours. }\end{array}$ \\
\hline HealthPrior21.com & $\begin{array}{l}\text { This platform offers health news and information, e-appointment, e- } \\
\text { library, videos, and an e-store etc. }\end{array}$ \\
\hline $\begin{array}{l}\text { D.Net (Development } \\
\text { Research Network) }\end{array}$ & It provides e-Health services through their tele-centers. \\
\hline
\end{tabular}

\subsection{Digital initiatives for social impact}

Recently, the Bangladeshi Government, private sector and NGOs have delivered voice messages to mobile subscribers in rural areas with the aim of increasing utilization of community clinic health services for primary healthcare (Islam, 2015).

\section{BANGLADESH'S HEALTH SYSTEM}

Depending upon the type of services patients required, the level of health care can be divided into three broader categories shown in table 3 . 
Table 3 Levels of Healthcare Services in Bangladesh

\begin{tabular}{lll}
\hline $\begin{array}{l}\text { Categories } \\
\text { of Services }\end{array}$ & Features & Remarks \\
\hline Primary Care & $\begin{array}{l}\text { Basic or General Healthcare Upazila hospitals are } \\
\text { responsible for it. }\end{array}$ & \multicolumn{2}{c}{ Ahmed et al., 2014 } \\
Secondary & $\begin{array}{l}\text { Medical care provided by a physician } \\
\text { Care }\end{array}$ & $\begin{array}{l}\text { Medical colleges and hospitals are responsible for } \\
\text { specialized healthcare services }\end{array}$ \\
\hline
\end{tabular}

\section{a Policy initiatives}

In fact, Bangladesh is currently in the process of adopting a framework for eHealth and mHealth, based on a decade of experience. The year 1998 is a milestone for eHealth in Bangladesh as the first eHealth project was launched by Swinfen Charitable. It involved a collaboration between the Centre for the Rehabilitation of the Paralyzed (CRP) in Bangladesh and the Royal Navy Hospital Haslar. As part of the 2008 _Digital Bangladesh" campaign, the public, private and nongovernment organizations (NGOs) have started using mHealth in Bangladesh with approximately 20 mHealth initiatives (Ahmed T., at, el., 2014), including primary healthcare, disease surveillance and data collection, health promotion and disease prevention, and health information systems and support tools (Khatun F., 2014). During the same year, the Ministry of Health and Family Planning Welfare (MoHFW) initiated their first eHealth initiative i.e. Program (HPNSDP) 2011-2016 for Ministry of Health and Family Welfare (MoHFW). The HPNSDP 2011-2-16 comprises 32 operational plans (DGHS, 2012) of which one is the e-Health (Health Bulletin, 2017).

\section{b Digital initiatives in government hospital of Bangladesh}

Bangladesh government has a wider range of specific programs to gradually improve the e-Health infrastructure and its use in the country. In April 2009, Bangladesh has established the Internet connectivity across all health points down to the Upazila level and in 2012 three hospitals have been included for automation (DGHS, 2012). Currently, most of the private clinics and hospitals in Bangladesh are using their own database system for patient health records i.e. Apollo Hospitals, Square Hospitals \& United Hospital. 19 September of the year 2011 was a notable day for Bangladesh for the recipient of the United Nations ICT award titled, -Digital Nations General Assemblyll. According to Health Bulletin, 2017, Healthcare sector is providing eService to the mass people through the information technologies i.e.

Usage of Mobile phone for healthcare service, Telemedicine, Telemedicine service in Community Clinics,

Telecare, Telemedicine in Union information and service centers, Complaints-suggestions through SMS, Pregnancy Care advice through SMS, Health statistics by SMS, Hospital Automation, Electronic Health Record (EHR), Online Population Health Registry, Attendance Monitoring System, Human Resources Databases, Online Processing of Dental-Medical Admission Tests, ADP Progress Monitoring System, GIS in Health Service, Schedule Management Software, Bulk SMS, Digital training facility and internet connectivity in health system (Health Bulletin, 2017). 


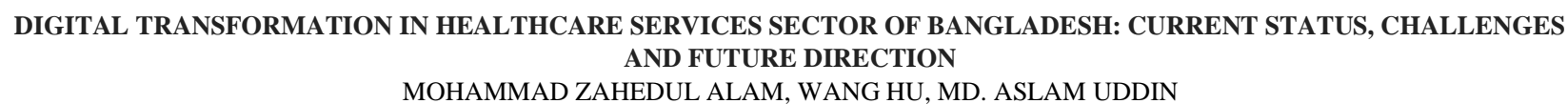

MOHAMMAD ZAHEDUL ALAM, WANG HU, MD. ASLAM UDDIN

\section{CHALLENGES}

The difficulties and challenges facing the digitalization of healthcare based on previous studies shown in the following table 4 .

Table 4 Challenges of Digital Transformation in Healthcare Services Sector of Bangladesh

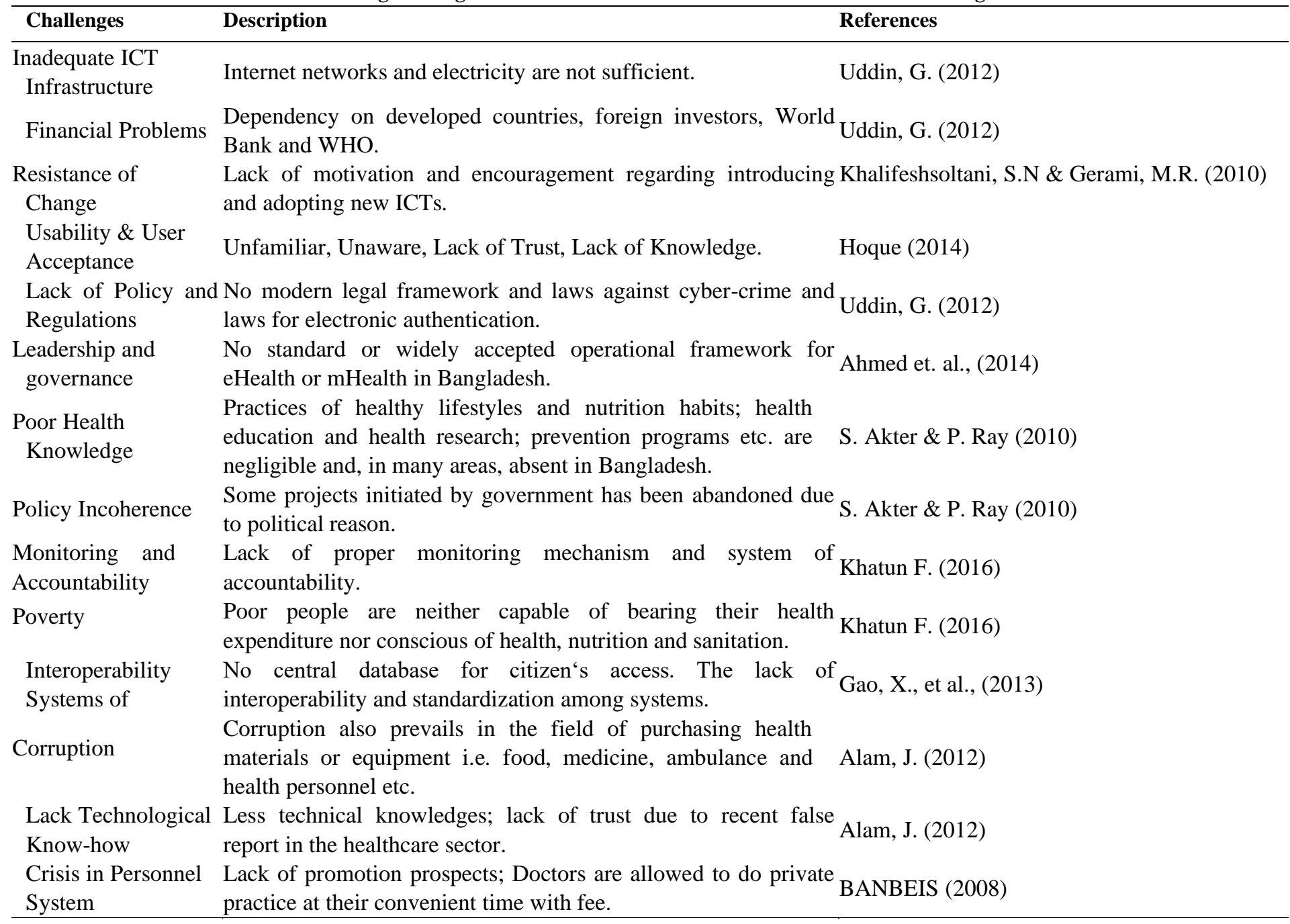

Over the last couple of years, although the healthcare community has witnessed many improvements in methods and technologies used in healthcare delivery, including mHealth as an emerging area of healthcare applications to improve access, reduce cost, save time, money \& energy to healthcare services. However, challenges involved in implementing mHealth to optimal advantage do exist which are shown in the above table 4 .

\section{CONCLUSION}

Improving healthcare sector in Bangladesh is good but not sufficient and information technology has not been introduced significantly to improve its quality, affordability and accessibility of services to the mass people. The current study shows that the overall situation of digital health care services sector in Bangladesh is 
not up to the mark. Due to illiteracy, lack of technological know-how, and resistance to change, the recipients of this service are not well-known to these innovations in healthcare services. On the other hand, Bangladesh government has adopted strategic plan to improve this sector which is a critical part of the economy of Bangladesh. But the sensitivity to digital transformation in healthcare sector is conflicting. In this respect, it can be concluded that service providers have to build a quality ICT based health service that must be easily and widely available throughout the country. Government should develop policy guidelines to monitor and supervise the digitalization of healthcare sector. Future research can be conducted on e-health, m-health, telecare, telehealth, electronic health record, telemedicine, digital startups and video conferencing separately.

\section{REFERENCES}

ALAMI H., GAGNON M. P., FORTIN J. P. Digital health and the challenge of health systems transformation [J]. Health, 2017, Vol.3 (31):49-60.

ALAM, J. E-Governance in Bangladesh: Present Problems and Possible Suggestions for Future Development [J]. International Journal of Applied Information Systems (IJAIS), 2012, 4(8):107-119.

AHMED, T., LUCAS, H., KHAN, A. S., ISLAM, R., BHUIYA, A., \& IQBAL, M. eHealth and mHealth initiatives in Bangladesh: a scoping study [J]. BMC health services research, 2014, 14(1):1-9.

AKHTER, S., \& RAY, P. mHealth- an ultimate platform to serve the unserved [M]. IMIA Yearbook of Medical Informatics, 2010, 94-100.

BANBEIS, Bangladesh Bureau of Educational Information and Statistics, 2018-04-10.

ERWIN, B. M., FERON, T., DEPREZ, R., REYNDERS, B., VAN DEN BOSCH, B. Trends in PACS Architecture [J]. Eur. J. Radiol, 2011, 4(1):199-204.

GAO, X., XU, J., SORWAR, G. \& CROLL P. Implementation of E-Health Record Systems and E-Medical Record Systems in China [J]. The International Technology Management Review, 2013:3(2):127-139.

HOQUE, R., MAZMUM, F. A., AHSAN \& YUKU. B. e-Health in Bangladesh: Current status, Challenges and Future direction [J]. The International Technology Management Review, 2014, 4(2):87-96.

IVATURY, G., MOORE, J., AND BLOCH, A. A Doctor in Your Pocket: Health Hotlines in Developing Countries [J]. Innovations: Technology, Governance, Globalization, 2016, 4(1):119-153.

ISLAM, M. S. Introducing modern technology to promote transparency in health services [J]. International Journal of Health Care Quality Assurance, 2015, 28(6):611-620.

BAUER, J, C. Rural America and the Digital Transformation of Health Care: New Perspectives on the Future [J]. Journal of Legal Medicine, 2002, 23(1):73-83.

KHALIFEFSOLTANI, S. N. \& GOURAMI M. E-Health Challenges, Opportunities and Experiences of Developing Countries [C]. International Conference on e-Education, e-Business, Sanya, China (IC4E): 2010. 
KHATUN, F. HEYWOOD, A. E., RAY, P. K., BHUIYA, A., LIAW, S-T. Community readiness for adopting mHealth in rural Bangladesh: A qualitative exploration [J]. International Journal of Medical Informatics 93, 2016:49-56.

Prospects of mHealth to improve the Health of Disadvantaged Population in Bangladesh [J]. CRC Press, 2015, 207-219.

MOSTAFA, R., RAHMAN, G.M.A., HASAN, G.M., KABIR, A., RAHMAN, A. \& ASHIK, S. Proposed Deployments to Provide E-Healthcare in Bangladesh: Urban and Rural Perspectives [C]. $12^{\text {th }}$ IEEE International Conference on e-Health Networking Applications and Service, 2016.

UDDIN, G. E-governance of Bangladesh: Present Scenario, Expectation, Ultimate Target and Recommendation [J]. International of Journal of Scientific and Engineering Research, 2012, 3(11):81-97. 